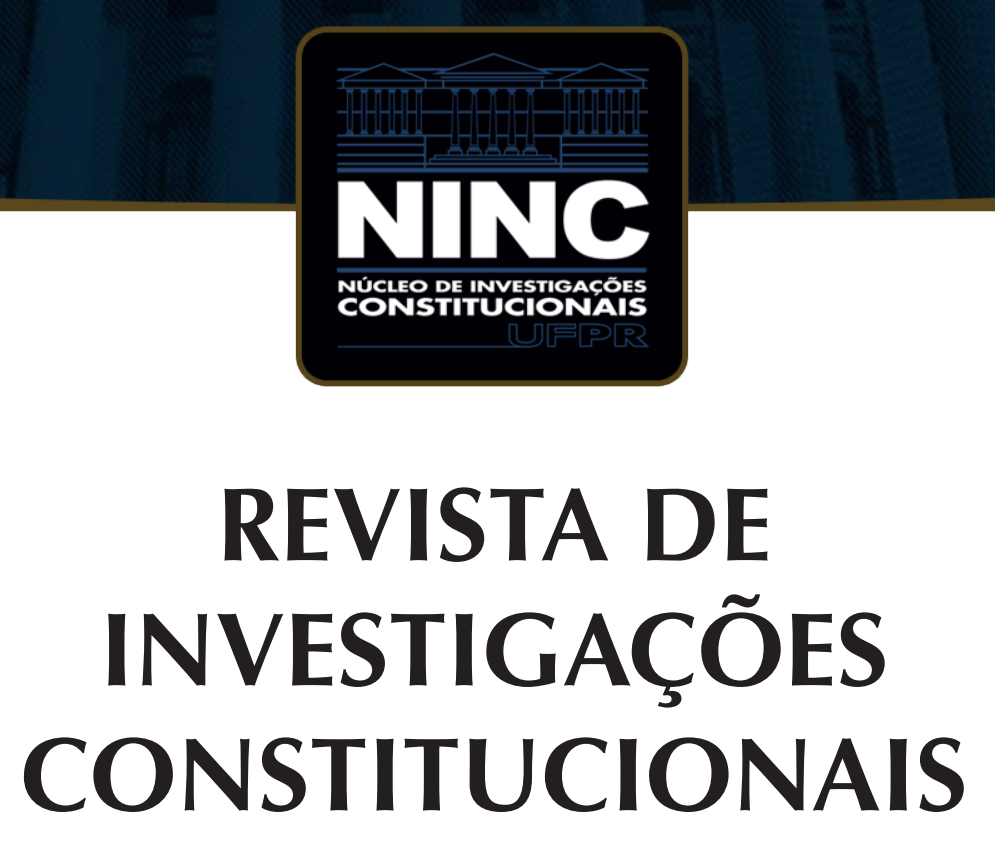

JOURNAL OF CONSTITUTIONAL RESEARCH

vol. 7 | n. 2 | maio/agosto 2020 | ISSN 2359-5639 | Periodicidade quadrimestral Curitiba | Núcleo de Investigações Constitucionais da UFPR | www.ninc.com.br 


\title{
A tutela do direito à saúde pela Administração Pública: delineando o conceito de tutela administrativa sanitária
}

\section{The protection of the right to health by the Public Administration: outlining the concept of health administrative protection}

\author{
LIGIA MARIA SILVA MELO DE CASIMIRO I, * \\ ' Universidade Federal do Ceará (Fortaleza, Ceará, Brasil) \\ meloligia@gmail.com \\ https://orcid.org/0000-0001-7987-4381
}

THANDERSON PEREIRA DE SOUSA $"$ ***

" Universidade Federal de Santa Catarina (Florianópolis, Santa Catarina, Brasil) thandersonsousa@hotmail.com https://orcid.org/0000-0003-0725-3572

Recebido/Received: 24.01.2020 / January $24^{\text {th }}, 2020$ Aprovado/Approved: $29.10 .2020 /$ October $29^{\text {th }}, 2020$

\section{Resumo}

O fenômeno da judicialização da saúde centraliza, predominantemente, o debate de dilemas decorrentes da política pública no âmbito do Poder Judiciário. Dessa maneira, esta pesquisa tem por intuito estabelecer uma perspectiva administrativa específica para a proteção do direito à saúde. A problemática gira, então, em torno do delineamento da noção de tutela administrativa para a saúde, seus elementos e fundamentos jurídicos. A abordagem metodológica é do tipo indutiva, apoiando-se nas técnicas de pesquisa bibliográfica e documental.

\section{Abstract}

The phenomenon of health judicialization centralizes, predominantly, the discussion of dilemmas arising from public policy in the context of the Judiciary Power. Thus, this research aims to establish a specific administrative perspective for the protection of the right to health. The problem revolves, then, around the delineation of the notion of administrative protection for health, its elements and legal foundations. The methodological approach is inductive, based on bibliographic and documentary research techniques. It is concluded that the right to health and the respective public

Como citar esse artigo/How to cite this article: CASIMIRO, Ligia Maria Silva Melo de; SOUZA, Thanderson Pereira de. A tutela do direito à saúde pela Administração Pública: delineando o conceito de tutela administrativa sanitária. Revista de Investigações Constitucionais, Curitiba, vol. 7, n. 2, p. 601-629, maio/ago. 2020. DOI: 10.5380/rinc.v7i2.71320.

"Professora Adjunta de Direito administrativo da Universidade Federal do Ceará (Fortaleza-CE, Brasil). Doutora em Direito Econômico e Desenvolvimento pela Pontifícia Universidade Católica do Paraná. Mestre em Direito do Estado pela Pontifícia Universidade Católica de São Paulo. E-mail: meloligia@gmail.com.

"Doutorando pelo Programa de Pós-graduação em Direito da Universidade Federal de Santa Catarina (Florianópolis-SC, Brasil). Mestre pelo Programa de Pós-graduação em Direito da Universidade Federal do Ceará (Fortaleza, CE, Brasil). Professor e advogado. E-mail: thandersonsousa@hotmail.com. 
Conclui-se que o direito à saúde e a política pública respectiva merecem gozar de tutela administrativa propriamente sanitária, a impulsionar o protagonismo da Administração e minimizar situações de conflito, equilibrando as dimensões objetiva e subjetiva.

Palavras-chave: direito à saúde; judicialização; proteção administrativa; tutela sanitária; escolha pública. policy deserve to enjoy administrative protection properly sanitary, to boost the protagonism of the Administration and minimize conflict situations, balancing the objective subjective dimensions.

Keywords: right to health; judicialisation; administrative protection; health protection; public choice.

\section{SUMÁRIO}

1. Introdução; 2. Tutela administrativa do direito à saúde; 3. Elementos da tutela administrativa sanitária; 4. Fundamentos para a tutela administrativa sanitária; 5. Conclusão; 6. Referências.

\section{INTRODUÇÃO}

Tem-se debatido amplamente nos últimos anos o fenômeno de judicialização da saúde, de sobremodo da política nacional de medicamentos. Há de se destacar que a exigibilidade do direito à saúde (art. 6, Constituição de 1988) fez com que, predominantemente, as discussões sobre os problemas advindos da política pública respectiva fossem concentradas no âmbito do Poder Judiciário.

Assim, o Supremo Tribunal Federal - STF proferiu decisões paradigmáticas no contexto do fornecimento de medicamentos, organizou audiência pública; o Conselho Nacional de Justiça - CNJ instituiu em 2010, com a Resolução no 107, o Fórum Nacional do Judiciário para monitoramento e resolução das demandas de assistência à saúde - Fórum da Saúde; CNJ promoveu, ainda, jornadas de direito à saúde, que resultaram em enunciados interpretativos, criou o Núcleo de Apoio Técnico aos magistrados - NAT JUS; ${ }^{1}$ e, em 2018, o Superior Tribunal de Justiça - STJ definiu, em julgamento de recurso repetitivo, critérios objetivos para a concessão de medicamentos não previstos no Sistema Único de Saúde - SUS.

Ocorre que, pelo exposto, há um protagonismo evidente do Judiciário em detrimento de abordagens envolvendo a Administração, responsável pela concretização de políticas públicas, e o Poder Legislativo, que - nas suas funções - pode desempenhar papel positivo na persecução da proteção e promoção da saúde.

Nessa conjectura, a problemática da pesquisa gira em torno do estabelecimento de um tratamento administrativo dos problemas envolvendo a política pública de saúde, indagando: em que termos é possível engendrar proteção administrativa para

\footnotetext{
MARIANO, Cynara Monteiro; FURTADO, Emanuel Teófilo; ALBUQUERQUE, Felipe Braga; PEREIRA Fabrícia Helena Linhares Coelho da Silva. Diálogos Sanitários Interinstitucionais e a experiência de implantação do NAT-JUS. Revista de Investigações Constitucionais, Curitiba, vol. 5, n. 1, p. 169-188, jan./abr. 2018. Disponível em: <https://revistas.ufpr.br/rinc/article/view/56027/35009>. Acesso em: 01 nov. 2018.
} 
o direito à saúde? Quais elementos constituem um arranjo protecionista? Que fundamentos jurídicos o sustentam?

É propósito da investigação demonstrar que no âmbito administrativo há possibilidade para a criação de espaços de avaliação/resolução de impasses no SUS, na qualidade de política pública corporificadora do direito à saúde, considerando que o caráter prestacional dos direitos sociais impõe o dever de efetivação e, simultaneamente, de criatividade procedimental necessário para proteção de direitos.

Desenvolve-se, metodologicamente, uma abordagem de estudo com caráter indutivo. Por intermédio da observação de demandas judiciais - envolvendo o sistema público de saúde - realizam-se constatações sobre as repercussões da judicialização para, posteriormente, desaguar na teorização acerca da tutela administrativa sanitária. São empregadas, nesse contexto, as técnicas de pesquisa documental e bibliográfica.

Em consequência, verifica-se que a judicialização cria ou modifica as configurações das escolhas públicas em matéria de saúde, havendo concentração de esforços especificamente no aperfeiçoamento da atuação dos Tribunais. A partir disso, é lançada a ideia de proteção administrativa do direito à saúde por meio do instituto da tutela sanitária, visando estimular o protagonismo da Administração Pública. A pesquisa está estruturada em três seções que abordam (i) considerações sobre a tutela administrativa em saúde, (ii) seus elementos e (iii) alicerces jurídicos.

\section{TUTELA ADMINISTRATIVA DO DIREITO À SAÚDE}

O direito à saúde necessita, inequivocamente, gozar de proteção administrativa capaz de lidar com os problemas que decorrem de sua previsão - integral e universal, para que desse modo exista uma implementação eficiente, igualitária e capaz de corporificar os objetivos da Constituição Federal de $1988 .^{2}$

Os avanços na medicina, sobretudo no que concerne à matéria de medicamentos, são rápidos. Novos medicamentos, tratamentos e técnicas terapêuticas são criadas para garantir a qualidade de vida e sobrevida do ser humano. Em 2012, as notificações de produtos sanitários chegaram ao número de 37.419 e, em 2017, as notificações cresceram consideravelmente, totalizando 54.545 registros. Desse quantitativo, 38,5\% são referentes a notificações de novos medicamentos. ${ }^{3}$ Contudo, é necessário pontuar que o Estado não tem condições de acompanhar, no contexto do Sistema Único de Saúde

\footnotetext{
2 PIVETTA, Saulo Lindorfer. Políticas públicas e a construção do conteúdo material do direito à saúde: desafio à Administração Pública brasileira. A\&C - Revista de Direito Administrativo \& Constitucional, Belo Horizonte, ano 10, n. 41, p. 209-230, jul./set. 2010.

3 MARTINS, Mary Anne Fontenele; GALATO, Dayani. Irregularidades dos medicamentos comercializados no Brasil: uma análise das notificações e das medidas sanitárias de 2012 a 2017. Vigilância Sanitária em Debate: sociedade, ciência e tecnologia, Rio de Janeiro, [s.I.], vol. 6, n. 4, p.23-33, 2018. Disponível em: <https://visaemdebate.incqs.fiocruz.br/index.php/visaemdebate/article/view/1165>. Acesso em: 02 set. 2018.
} 
- SUS, essas atualizações, pois há limitação financeira que obriga a realização de escolhas estratégicas.

Analisando amostra de mandados de segurança, entre os anos de 2015 e 2017, no âmbito do Tribunal de Justiça do Estado do Piauí - TJPI, com margem de erro da pesquisa em $10 \%$ e nível de segurança fixado em $95 \%$, constata-se: $86 \%$ dos processos têm caráter individual, enquanto os mandados de segurança coletivos somam 14\%, apenas; de modo geral, $77 \%$ das demandas judiciais analisadas tratam de medicamentos não previstos nos Protocolos Clínicos e Diretrizes Terapêuticas e na RENAME. ${ }^{4}$

Diante desses números, pode-se perceber duas situações: (1) as ações individuais, em nível expressivo, interferem na concretização da política pública, restando elaborada um novo arranjo - distante das disposições constitucionais e infraconstitucionais - e, a seu turno, (2) as ações coletivas alteram as escolhas públicas.

As demandas individuais, buscando o fornecimento de medicamentos não previstos na listagem oficial do sistema público de saúde, ${ }^{5}$ findam por criar, efetivamente, quando deferidos os pedidos, uma nova política pública, alheia ao SUS e em detrimento deste. Nessa perspectiva, Vanice Regina Lírio do Valle observa que "também no campo da proteção ao direito à saúde [...] tem-se a ampliação progressiva da gama de bens ou de serviços correlatos que devam se compreender na proteção judicial", ${ }^{\prime \prime}$ entretanto a ampliação de bens e serviços não alcança todos os cidadãos de maneira objetiva.

Na matriz coletiva, passa-se a "exigir uma atuação de cunho universal e equânime em favor de um determinado segmento [...]; ou, ainda, a retificação das ações públicas relacionadas à superação de uma deficiência", a modificar a escolha pública em matéria de saúde sem planejamento e ${ }^{8}$ igualmente, sem as condições e expertise necessárias para determinar as consequências das suas decisões.

\footnotetext{
4 MARTINS, Mary Anne Fontenele; GALATO, Dayani. Irregularidades dos medicamentos comercializados no Brasil: uma análise das notificações e das medidas sanitárias de 2012 a 2017. Vigilância Sanitária em Debate: sociedade, ciência e tecnologia, Rio de Janeiro, [s.l.], vol. 6, n. 4, p.23-33, 2018. Disponível em: <https://visaemdebate.incqs.fiocruz.br/index.php/visaemdebate/article/view/1165>. Acesso em: 02 set. 2018.

5 DAL POZZO, Emerson Luís; MION, Ronaldo de Paula. Controle jurisdicional das políticas públicas de saúde através da inclusão de medicamentos na relação de medicamentos essenciais do Sistema Único de Saúde. A\&C - Revista de Direito Administrativo \& Constitucional, Belo Horizonte, ano 19, n. 77, p. 199-228, jul./set. 2019.

6 VALLE, Vanice Regina Lírio do. Políticas públicas, direitos fundamentais e controle judicial. 2. Ed. Belo Horizonte: Editora Fórum, 2016, p. 133.

7 VALLE, Vanice Regina Lírio do. Políticas públicas, direitos fundamentais e controle judicial. 2. Ed. Belo Horizonte: Editora Fórum, 2016, p. 123.

8 Sobre a relevância do planejamento para a adequada tutela dos direitos fundamentais sociais, ver: CASIMIRO, Ligia Maria Silva Melo; MORAES, Filomeno. Planejamento social na Administração Pública: um instrumento essencial na promoção dos direitos fundamentais sociais. Revista de Direito Econômico e Socioambiental, Curitiba, v. 8, n. 2, p. 443-461, maio/ago. 2017; CASIMIRO, Lígia Maria Silva Melo de. A participação social no planejamento das políticas públicas urbanas. Revista Eurolatinoamericana de Derecho Administrativo, Santa Fe, vol. 4, n. 1, p. 7-21, ene./jun. 2017.
} 
Pelo exposto, há uma dúvida razoável quanto à atuação dos magistrados na judicialização da saúde, uma vez que se expõe o problema de capacidade institucional, conforme indicam Ana Paula Ávila e Karen de Melo, ${ }^{9}$ informando - adicionalmente que existem dificuldades de capacidade, particularmente com relação aos protocolos de medicina apoiados em evidências.

É preciso fortalecer, no âmbito do fornecimento de medicamentos, a ideia de que se é de responsabilidade da Administração Pública realizar escolhas, considerando uma dimensão sustentável, que isto ocorra de fato, em sua integralidade. ${ }^{10}$

Nesse contexto, a tutela administrativa pode funcionar como uma proposição para superar o protagonismo judicial na questão do fornecimento de fármacos e também em outras áreas sanitárias, vez que reforça na Administração, responsável pela concreção de políticas públicas, a responsabilidade pela proteção dos direitos fundamentais e resolução de conflitos deles decorrentes, combatendo de modo hábil situações problemáticas causadas pela atuação judicial e pelos desafios em assegurar o direito à saúde, contribuindo para a minimização da judicialização e melhorando a qualidade dos serviços públicos. ${ }^{11}$

Alexandre Santos de Aragão, ${ }^{12}$ abordando o tema da tutela administrativa, determina que esta, apesar da incoerência do termo "tutela", significa o controle ou supervisão dos entes políticos para com as atividades das entidades da Administração Indireta, possuindo, inclusive, determinação constitucional (art. 87, CF/88). Ainda para o autor, a tutela administrativa é um poder de supervisão ou controle específico, desta forma as entidades da Administração Indireta federal, estadual ou municipal estão ligadas apenas ao ministério/secretaria do qual tenham afinidade substancial. No âmbito da União, a tutela é regida pelo Decreto-lei n 200 de 1967, que detém nível hierárquico de lei ordinária, podendo haver a substituição de suas disposições em função de lei específica, não há referência expressa ao termo "tutela administrativa", mas a denominação de "supervisão ministerial".

\footnotetext{
9 ÁVILA, Ana Paula Oliveira; MELO, Karen Cristina Correa de. Separação de poderes e diálogos institucionais nos litígios envolvendo o direito à saúde. Revista de Investigações Constitucionais, Curitiba, vol. 5, n. 1, p.83108, 1 jan. 2018, p. 96-97. Disponível em: <https://revistas.ufpr.br/rinc/article/view/54934/35005>. Acesso em: 26 nov. 2019.

10 VALLE, Vanice Regina Lírio do. Sustentabilidade das escolhas públicas: dignidade da pessoa traduzida pelo planejamento público. A\&C - Revista de Direito Administrativo \& Constitucional, Belo Horizonte, ano 11, n. 45, p. 127-149, jul/set, 2011, p. 145. Disponível em: <http://www.revistaaec.com/index.php/revistaaec/article/ view/212>. Acesso em: 02 set. 2018.

11 Nessa linha, ver: CAMBI, Eduardo; VASCONCELOS, João Paulo A. Desjudicialização de políticas públicas e o Novo Código de Processo Civil - Contributo do Ministério Público e da Advocacia Pública à solução extrajudicial de conflitos. A\&C - Revista de Direito Administrativo \& Constitucional, Belo Horizonte, ano 16, n. 64, p. 225-251, abr./jun. 2016.

12 ARAGÃO, Alexandre Santos de. Curso de direito administrativo. 2. Ed. Rio de Janeiro: Forense, $2013, \mathrm{p}$. 245.
} 
Por outro lado, José Cretella Júnior define a expressão tutela administrativa como a "[...] técnica que designa, dum modo geral, a fiscalização que o Estado exerce sobre um órgão descentralizado, dentro dos limites que a lei assinala".13 Maria Sylvia Zanella Di Pietro ${ }^{14}$ orienta que a tutela administrativa é uma espécie de controle que recai, de modo particular, sobre entidades da Administração Indireta, com atos e aspectos possíveis de controle predeterminados legalmente. Hely Lopes Meirelles, ${ }^{15}$ no que lhe concerne, não utiliza o termo tutela administrativa, em sua teoria prefere designar o fenômeno da supervisão e controle, nos termos substanciais indicados pelos autores antes mencionados, de controle autárquico.

Há, ainda, a percepção da tutela administrativa enquanto um princípio setorial da Administração Pública, que vincula os órgãos da Administração Indireta à fiscalização de legalidade exercida por parte dos órgãos da Administração Direta, inexistindo subordinação hierárquica, não podendo o dito controle ser exercido sem previsão legal, não sendo, portanto, presumível a tutela.

Pelo exposto, é possível verificar que a noção de tutela administrativa que foi construída no Direito Administrativo brasileiro, de maneira clara, está ligada aos procedimentos de controle e supervisão dos atos praticados pela Administração Pública Indireta, devendo a atitude tutelar estar descrita e limitada pela legislação.

Entretanto, a tutela administrativa que surge como proposição ao enfrentamento de problemas na concretização do direito social à saúde se distingue, essencialmente, da noção de tutela já construída na doutrina administrativista. Há, sem dúvidas, desacordos de ordens conceitual e procedimental.

María Pamela Tenreyro explica que, na perspectiva do Estado de Direito, os indivíduos convertem-se em cidadãos, o que consequentemente gera, de forma inquestionável, o compromisso e o dever de reconhecimento e garantia de direitos, bem como a corporificação de ferramentas garantidoras. ${ }^{16}$ No contexto das políticas públicas, que funcionam como instrumento de corporificação de direitos sociais, ${ }^{17}$ é necessário que exista, para além da concreção dos serviços públicos, acesso a ferramentas que busquem proteger os cidadãos e, ao mesmo tempo, funcionem como pontos de exercício da cidadania.

\footnotetext{
13 CRETELLA JÚNIOR, José. Definição da tutela administrativa. Revista de Direito Administrativo, Rio de Janeiro, vol. 96, p. 35, ago. 1969. Disponível em: <http://bibliotecadigital.fgv.br/ojs/index.php/rda/article/ view/32209>. Acesso em: 05 set. 2018.

14 PIETRO, Maria Sylvia Zanella Di. Direito administrativo. 31. Ed. Rio de Janeiro: Forense, 2018.

15 MEIRELLES, Hely Lopes. Direito administrativo brasileiro. 41. Ed. São Paulo: Malheiros Editores, $2014, \mathrm{p}$. 435-436.

16 PAMELA TENREYRO, María. Técnicas de tutela frente a la inactividad administrativa. Córdoba: Academia Nacional de Derecho y Ciências Sociales de Córdoba, 2012, p. 46-47.

17 CARVALHO, Osvaldo Ferreira de. As políticas públicas como concretização dos direitos sociais. Revista de Investigações Constitucionais, Curitiba, vol. 6, n. 3, p. 773-794, set./dez. 2019. Disponível em: <https://revistas.ufpr.br/rinc/article/view/59730/40602>. Acesso em: 05 dez. 2019.
} 
Desse modo, a materialização de direitos não deve ser concebida somente por intermédio de princípios e regras - depende também de formulação de políticas públicas, considerado o risco de transformarem-se em "normas mortas". O compromisso com a defesa da operatividade estrutural de direitos, com a cidadania e com a democracia constitui elemento indispensável para o funcionamento adequado do Estado.

Portanto, o compromisso com a proteção de direitos, a ser consolidado em ferramentas que permitam o exercício da cidadania, não pode ser interpretado exclusivamente enquanto garantias processuais em sentido estrito - referindo-se à atividade judicial de controle administrativo - ou meios de controle interno.

Não se expressa como razoável a vinculação da proteção de direitos fundamentais somente aos aparatos de controle clássicos, especialmente no Brasil, pois com o advento da Constituição de 1988 as tarefas estatais aumentaram consideravelmente, demandando perspectivas de atuação criativas. O movimento que se deve estimular é, na verdade, o de estudo, identificação e instrumentalização de novos ductos de salvaguarda de direitos, distantes do Poder Judiciário, dentro das condições possíveis, criando espaço sinérgico para exercício da cidadania e concreção de garantias constitucionais.

Sob essa óptica, a Administração Pública deve atuar para que, institucionalmente, sejam estabelecidas condições procedimentais em que todos os cidadãos tenham acesso à proteção efetiva de seus direitos - de forma coletiva, privilegiando a dignidade humana, ${ }^{18}$ tornando-se arena visível de resolução de conflitos, auxiliando na diminuição de casos judicializados, contribuído para o funcionamento equilibrado e harmônico dos Poderes do Estado.

Opondo-se à ideia suscitada, pode-se levantar a tese de que, no contexto jurídico brasileiro, fora dos limites estabelecidos pela Constituição de 1988 e por outros instrumentos normativos infraconstitucionais, não haveria a possibilidade de implementação de instrumentos protetivos de direitos, salvo os casos advindos da atividade do Poder Legislativo.

Tal argumento não se sustenta, tendo em vista que, apesar de a Constituição de 1988 indicar formalmente mecanismos de controle (mandado de segurança, mandado de injunção, ação popular e ação civil pública; e, pela própria Administração Pública - art. 74, internamente), há um prisma substancial que, conjugando (1) dignidade humana e (2) princípios que regem a atuação administrativa, autoriza a edificação de engrenagens para o desenvolvimento humano e proteção de direitos. Destarte, Daniel Hachem revela que "[...] as ações administrativas, nesse quadro, não são limitadas pelo

18 MEZZAROBA, Orides; SILVEIRA, Vladmir Oliveira da. The principle of the dignity of human person: A reading of the effectiveness of citizenship and human rights through the challenges put forward by globalization. Revista de Investigações Constitucionais, Curitiba, vol. 5, n. 1, p. 273-293, jan./abr. 2018. Disponível em: <https://revistas.ufpr.br/rinc/article/view/54099/35013>. Acesso em: 05 set. 2018. 
ordenamento jurídico [...], mas também incitadas e programadas pelo sistema constitucional e legal mediante determinações normativas impositivas". ${ }^{19}$

Isso posto, a Administração Pública deve ser criativa, no sentido de buscar meios de implementar objetivamente os direitos de caráter prestacional, tateando mecanismos que busquem a efetivação coletiva de direitos..$^{20} \mathrm{~A}$ inatividade administrativa, nesse cenário, contribui para a acentuação da desigualdade entre os cidadãos, ferindo a integridade do interesse público e, claramente, fortalecendo o descrédito na atuação do administrador. Em tal caso, Daniel Hachem pondera que a ausência de atuação administrativa pode ser um problema mais significativo do que ações positivas incompatíveis com parâmetros constitucionais e legais, de modo que para o autor não faz sentido garantir liberdades ao cidadão ante a inexistência de condições de efetivo exercício. ${ }^{21}$

Para viabilizar a proteção dos cidadãos e de seus respectivos direitos, assim como equilibrar as dimensões objetivas e subjetivas das garantias constitucionais no Brasil, Daniel Hachem, ${ }^{22}$ em sua tese, propõe um conceito de tutela administrativa que, considerando as bases lançadas anteriormente, aproxima-se de uma percepção de tutela que não está vinculada, necessariamente, ao controle em uma compreensão restritiva, ou seja, se distancia da idealização da tutela administrativa apenas como controle da Administração Direta em relação à Indireta.

Insta salientar que, de fato, é um grande avanço identificar o dever de protagonismo da Administração Pública por intermédio da tutela nos termos prescritos por Hachem. Entretanto, é útil reconhecer que os problemas que envolvem a Administração Pública, seus deveres e o conteúdo de direitos fundamentais são policêntricos, isto é, provenientes de vários eixos que se cruzam na experiência da gestão pública, inclusive com raízes de ordem jurídica.

O direito à saúde, mormente na assistência terapêutica pública e sua concreção, é caso notável de policentrismo, a desafiar as fronteiras dos tradicionais controles

\footnotetext{
19 HACHEM, Daniel Wunder. Tutela administrativa efetiva dos direitos fundamentais sociais: por uma implementação espontânea, integral e igualitária. 2014. 625 f. Tese - Doutorado em Direito, Setor de Ciências Jurídicas - Programa de Pós-Graduação em Direito, Universidade Federal do Paraná - UFPR, Curitiba, 2014 , p. 238.

20 HACHEM, Daniel Wunder. São os direitos sociais "direitos públicos subjetivos"? Mitos e confusões na teoria dos direitos fundamentais. Revista de Estudos Constitucionais, Hermenêutica e Teoria do Direito, São Leopoldo, v. 11, n. 3, p. 404-436, set./dez. 2019. p. 428.

21 HACHEM, Daniel Wunder. Tutela administrativa efetiva dos direitos fundamentais sociais: por uma implementação espontânea, integral e igualitária. 2014. 625 f. Tese - Doutorado em Direito, Setor de Ciências Jurídicas - Programa de Pós-Graduação em Direito, Universidade Federal do Paraná - UFPR, Curitiba, 2014, p. 240-242.

22 HACHEM, Daniel Wunder. Tutela administrativa efetiva dos direitos fundamentais sociais: por uma implementação espontânea, integral e igualitária. 2014. 625 f. Tese - Doutorado em Direito, Setor de Ciências Jurídicas - Programa de Pós-Graduação em Direito, Universidade Federal do Paraná - UFPR, Curitiba, 2014, p. 291.
} 
interno e externo da Administração. Celso Barberato e Zaiden Geraide Neto, ${ }^{23}$ reconhecendo as dificuldades que envolvem a implementação do direito à saúde, nos termos em que foi constitucionalizado e regulado infraconstitucionalmente, afirmam, de modo certeiro, que os imbróglios da saúde no Brasil decorrem inclusive da polissemia do termo "direito", dos significados variados que possui. Posto isso, resta, nessa senda, reforçada a tese do policentrismo problemático que incide sobre direitos, sobretudo na saúde.

O regime de bem-estar - como característica do Estado de Direito Democrático Social - se mantém, muito embora haja verdadeiro risco de comprometimento de alguns aspectos das prestações materiais, ${ }^{24}$ essa situação torna-se clarividente no cenário da saúde pública brasileira, demandando formas ousadas de atuação administrativa e proteção de direitos.

Diante do exposto, elabora-se uma proposta conceitual de proteção por intermédio da tutela administrativa sanitária, que se traduz no (a) poder-dever da Administração Pública em atuar, voluntariamente ou por solicitação do cidadão, para deslindar questões controversas e, potencialmente, violadoras do direito fundamental social à saúde, bem como de outras garantias dele decorrentes, (b) mediante órgão independente e autônomo, integrado à estrutura do Sistema Único de Saúde - SUS, (c) adotando as técnicas concertadas necessárias, podendo desaguar em atos próprios do controle interno, (d) com decisões de caráter resolutivo e vinculante.

Útil apontar, nesta altura, que o sucesso da tutela administrativa sanitária depende não somente da disponibilização de arena para resolução de questões problemáticas. É necessário, igualmente, que a Administração Pública adote medidas no sentido de conscientizar e educar os cidadãos sobre a possibilidade de resolução administrativa de conflitos, contribuindo para uma modificação efetiva na cultura da judicialização que é manifesta no Brasil.

A educação para uma cultura concertada torna-se instrumento de cidadania, cooperando com o desenvolvimento de características democráticas e dialógicas no âmbito do Sistema Único de Saúde - SUS, rompendo o caráter formal da participação comunitária na gestão, controle e fiscalização do sistema. Ademais, não é possível, no contexto do Estado de Direito, vedar o Judiciário de apreciar lesão ou ameaça a direitos, por força do disposto no art. 5, XXXV, da Constituição de 1988. Contudo, o diálogo e a educação para o consenso podem auxiliar na redução da hipertrofia judicial em matéria de saúde pública.

23 BARBERATO, Celso; GERAIDE NETO, Zaiden. O direito à saúde no contexto do neoconstitucionalismo. Nomos: Revista do Programa de Pós-graduação em Direito da UFC, vol. 32, n.2 p.107-126, dez. 2014. Semestral. Disponível em: <http://periodicos.ufc.br/nomos/article/view/1217>. Acesso em: 15 set. 2018.

24 SORENSEN, Georg. La transformación del Estado: mas allá del mito del repliegue. Trad. Ramón Cotarelo. Valencia: Tirant lo Blanch, 2010, p. 65. 


\section{ELEMENTOS INTEGRANTES DA TUTELA ADMINISTRATIVA SA- NITÁRIA}

O (a) poder-dever da Administração Pública é, de modo seguro, uma convenção constitucionalmente prevista. Uma vez que a cidadania e a dignidade humana constituem fundamentos do Estado brasileiro, não poderia se interpretar, razoavelmente, que a gestão da coisa pública pudesse estar limitada em sua atuação pela letra fria da norma, obstando ao administrador atuar de modo criativo para reforçar os fundamentos do Estado, e, consequentemente, atingir objetivos constitucionais.

O art. 196 da Constituição, ao determinar que a saúde é um direito de todos e dever do Estado, impõe que o administrador público busque implementar a proteção da saúde por meio do acesso universal e igualitário às ações e serviços. Pelo definido na Lei n 8.080 de 1990, art. 2 , o Estado deve prover as condições indispensáveis para o exercício pleno do direito à saúde. Realizando uma interpretação sistemática e teleológica dos referidos artigos, combinados com os fundamentos e objetivos da República, extrai-se que a Administração tem o poder para conformar o direito à saúde, e se tem o poder, tem o dever de agir para que o acesso às ações e serviços públicos de saúde sejam garantidos de forma coletiva e igualitária, sempre pautada nos princípios que regem a atividade administrativa: legalidade, impessoalidade, moralidade, publicidade e eficiência (art. 37, caput).

Nessa toada, o Estado pode e deve, espontaneamente ou por solicitação dos cidadãos, no contexto da saúde pública, averiguar as situações que, em tese, podem configurar-se enquanto fatos violadores de direitos fundamentais. A espontaneidade cria, de plano, a noção de uma gestão pública protagonista e desacomodada, que busca observar no ambiente estatal as condições de implementação de direitos, a concreção de políticas públicas, chamando para si e reforçando as responsabilidades estabelecidas pela CF/88 no que tange a proteção integral da saúde dos brasileiros, compreendendo as dificuldades de sua própria atuação e, indiretamente, observando novas perspectivas para a proteção efetiva da saúde e do sistema público.

De outra banda, a possibilidade de solicitação de avaliação de demandas pelos cidadãos, dirigida diretamente ao Estado sanitário, de forma simplificada, é canal para a democratização e garantia efetiva do direito à saúde, pois, dada a realidade brasileira, em que a tutela judicial não goza de acesso descomplicado, nem mesmo de facilidade de acesso - nessa área ainda seria necessário discutir "o direito de acesso ao acesso à tutela judicial" - tal abertura alarga, inquestionavelmente, o alcance do Sistema Único de Saúde - SUS para incluir os cidadãos que estão distantes dos Tribunais. 
Por essa lógica, Sandro Lucio Dezan e Samuel Brasil Júnior ${ }^{25}$ lecionam que é compreensível a proteção do direito à saúde pelo Estado, conduzindo, pois, diretamente ao poder-dever de gerir conflitos e tutelar direitos, independentemente de regulação normativa, mas em consonância com a lógica da juridicidade.

À revelia da ideia desenhada, poderia ser firmada a impossibilidade de abertura jurídica para formas criativas de resolução de problemas no âmbito administrativo. Havendo interesse da Administração Pública em atuar, internamente, para a proteção do direito à saúde, só o faria pelos meios consolidados de controle interno (recurso administrativo, poder hierárquico e tutela administrativa/controle autárquico etc.), quando cabíveis. No entanto, não merece prosperar tal fundamento, pois o princípio da legalidade diz respeito não somente ao seguimento da legislação, estritamente, mas, longe disso, deve ser concebido como a obediência às disposições constitucionais, bem como a princípios gerais de Direito, ${ }^{26}$ o que autoriza novos instrumentos de atuação na Administração Pública numa esteira juridicizadora.

Um (b) órgão independente e autônomo, mas integrado à estrutura do SUS, deve ser criado para receber as solicitações dos cidadãos ou, em outros casos, agir a pedido da própria Administração Pública, no sentido de garantir o acesso igualitário e universal às ações e serviços de saúde, especialmente no que toca o fornecimento de medicamentos, satisfazendo as diretrizes listadas no art. $7^{\circ}$ da Lei orgânica do SUS.

A Lei n 8.080/1990, considerando a unicidade de direção do SUS, conforme o art. 198, I, da CF/88, preceitua que haverá descentralização político-administrativa, havendo pontos de coordenação em cada esfera de governo (federal, estadual e municipal). ${ }^{27}$ No ensejo de organizar o sistema público de saúde, o legislador ordinário instituiu, ainda, as Comissões Intersetoriais, Comissões Permanentes de Integração e as Comissões Intergestores Bipartite e Tripartite.

As Comissões Intersetoriais realizam, em sua competência, a interação das estratégias e programas do SUS com áreas alheias ao sistema. As Comissões Permanentes, no que lhes dizem respeito, buscam firmar parcerias entre o SUS e as instituições de ensino. Por último, as Comissões Intergestores realizam, no que se refere aos aspectos operacionais do sistema, negociações e pactuações, mas, como a própria nomenclatura indica, esses atos são praticados entre gestores.

25 DEZAN, Sandro Lucio; BRASIL JÚNIOR, Samuel Meira. A juridicidade do Estado-administração na concretização de políticas públicas de saúde - Um método para a justificação da eficácia horizontal dos direitos fundamentais. A\&C - Revista de Direito Administrativo \& Constitucional, vol. 16, n. 63, p. 2015, jan./mar. 2016. Disponível em: <http://www.revistaaec.com/index.php/revistaaec/article/view/49>. Acesso em: 10 out. 2018.

26 PEREIRA JÚNIOR, Jessé Torres. Presença da administração consensual no direito positivo brasileiro. In: MOREIRA NETO, Diogo de Figueiredo (Coord.). Uma avaliação das tendências contemporâneas do direito administrativo. Rio de Janeiro: Renovar, 2003, p. 300.

27 BERTOTTI, Bárbara Mendonça; PIVETTA, Saulo Lindorfer. A integração da iniciativa privada ao sistema público de saúde brasileiro: limites e possibilidades. Revista Eurolatinoamericana de Derecho Administrativo, Santa Fe, vol. 5, n. 2, p. 239-265, jul./dic. 2018. 
Sob outra perspectiva, a Lei n 8.142 de 1990 disciplina a participação da comunidade no Sistema Único de Saúde e as transferências de recursos. Para viabilizar a integração da sociedade na gestão do sistema, o referido instrumento normativo instala a Conferência de Saúde e o Conselho de Saúde (art. 10, I e II). Nada obstante, é possível afirmar que a inclusão da comunidade na gestão do sistema público de saúde é apenas um compromisso formal. Fazendo uma analogia com a ideia de constitucionalização simbólica, ${ }^{28}$ a noção de participação comunitária, trazida pela Lei n 8.142/90, é eivada de simbolismo, uma vez que (a) as reuniões da Conferência de Saúde ocorrem somente de quatro em quanto anos, e, (2) apesar de os Conselhos serem órgãos colegiados permanentes e deliberativos, não têm como atribuição a solução de possíveis conflitos. É verdadeira previsão simbólica de gestão comunitária.

A Portaria de Consolidação no 1/2017-MS, reunindo os regulamentos dos direitos e deveres dos usuários do SUS, no art. $6^{\circ}, \mathrm{XI}$, assegura o direito de ser ouvido em suas manifestações por ouvidorias, urnas ou quaisquer outros instrumentos que a Administração dispuser. O art. 109 cria o Departamento de Ouvidoria do SUS, responsável pelo recebimento e tratamento de manifestações e, inovando, o art. 117, IV, indica que no rol de competências das ouvidorias do SUS se encontra a mediação administrativa, "com vistas à correta, objetiva e ágil instrução das demandas apresentadas pelos cidadãos, bem como a sua conclusão dentro do prazo estabelecido para resposta ao demandante",29 muito embora não esteja expresso como deverá acontecer a mediação.

Identifica-se a inexistência de uma instância capaz de resolver, efetivamente, situações controversas no âmbito do SUS, especialmente pelo generalizado caráter de urgência que os problemas que levam à judicialização da saúde possuem, como o fornecimento de medicamentos, por exemplo.

O órgão, institucionalizando a tutela administrativa sanitária, deve seguir a mesma estruturação do SUS: único e descentralizado entre as esferas de governo, permitindo uma maior capilaridade e alcance de sua atuação. É importante ressaltar que, apesar de integrar o sistema, nos moldes defendidos aqui, é preciso ser distinto da Administração ativa do SUS, garantindo a imparcialidade, objetividade, celeridade e efetividade nos casos em que atuar.

28 Constitucionalização simbólica diz respeito ao abismo existente entre hipertrofiadas disposições constitucionais e suas respectivas corporificações. O processo de construção simbólica de uma Constituição pode (1) firmar valores sociais, (2) demonstrar a capacidade do Estado e (3) resolver conflitos sociais com técnica de compromissos dilatórios. Para maiores esclarecimentos ver: NEVES, Marcelo. A constitucionalização simbólica. São Paulo: Martins Fontes, 2007.

29 BRASIL. Portaria de Consolidação n 1, de 28 de setembro de 2018. Consolidação das normas sobre os direitos e deveres dos usuários da saúde, a organização e o funcionamento do Sistema Único de Saúde. Diário Oficial da União, Brasília, DF, 28 de set. de 2017. Disponível em: <http://bvsms.saude.gov.br/bvs/saudelegis/ gm/2017/prc0001_03_10_2017_comp.html>. Acesso em: 16 out. 2018. 
A criação de tal figura não demanda, pelo exposto anteriormente, de uma previsão expressa da legislação. A criatividade para a tutela administrava sanitária poderá sustentar-se no poder-dever de proteção do direito fundamental à saúde, bastando atos de regulação emanados da autoridade administrativa. Porém, poderá ocorrer via proposição legislativa apresentada ao Congresso Nacional, consideradas as competências previstas no art. 24, XII, da Constituição de 1988.

Pensar em tal situação suscita, por questão lógica, a repercussão financeira que o Estado poderá sofrer, buscando a tutela administrativa sanitária. Mas diante disso, indispensável é revelar os valores que a União dirigiu para a satisfação de ações judiciais com o fornecimento de medicamentos e insumos: em 2016, o valor gasto foi de $\mathrm{R} \$$ 1.252.217.955,08; em 2017, somou R\$ 979.001.580,59; ${ }^{30}$ e, em 2018, as despesas da União chegaram a R\$1,25 bilhão. ${ }^{31}$ Os valores são consideráveis, comprometem diretamente a política pública de saúde. Ademais, vislumbra-se que não existem estudos que avaliem, com rigor, o impacto da judicialização nos orçamentos estaduais e municipais. ${ }^{32}$ Pelo exposto, o uso racional dos recursos públicos para arcar com a tutela administrativa sanitária pode, potencialmente, ser mais proveitoso do ponto de vista coletivo.

A (c) adoção de técnicas concertadas permite que a Administração Pública, no exercício de suas funções, maximize a proteção do direito à saúde, bem como a conservação de outros direitos dele decorrentes, utilizando-se de instrumentos criativos para a consumação de decisões administrativas, de forma flexível, sem implicar numa violação à legislação constitucional ou infraconstitucional sanitária.

O desenvolvimento humano levou, consequentemente, à transformações no Estado, desemborcando em novas formas de administrar a máquina pública, o que passou a pressupor uma relevância aumentada no que se refere aos atos e procedimentos administrativos. ${ }^{33}$ Por essa conjuntura, Eurico Bitencourt Neto aduz que "se a Administração Pública do século XXI prossegue múltiplos e, muitas vezes, concorrentes interesses públicos, o procedimento administrativo se consolida como a matriz principal de

30 Dados obtidos por consulta de informações do Ministério da Saúde, com base na Lei de Acesso à Informação. Protocolo n 25820005492301889. BRASIL. Sistema Eletrônico do Serviço de Informação Ao Cidadão. Ministério da Transparência. Acesso à informação. 2018. Disponível em: <https://esic.cgu.gov.br/sistema/site/ index.aspx>. Acesso em: 20 out. 2018.

31 BRASIL. Siga Brasil. Senado Federal. Siga Brasil painéis: Orçamento Federal. 2018. Disponível em: <https:// www12.senado.leg.br/orcamento/sigabrasil>. Acesso em: 20 out. 2018.

32 OBSERVATÓRIO DE ANÁLISE POLÍTICA EM SAÚDE (BAHIA). Instituto de Saúde Coletiva da UFBA. Judicialização na saúde: panorama aponta aumento de 727\% nos gastos da União. 2017. Disponível em: <https:// analisepoliticaemsaude.org/oaps/noticias/aefce52bac4b5a12668347eb6626c67f/>. Acesso em: 20 out. 2018.

33 CASSESE, Sabino. Le trasnformazioni del diritto amministrativo dal XIX al XXI secolo. Rivista trimestrale di diritto pubblico, Roma, vol. 1, p. 27-40, 2002, p. 35-36. 
uma atuação racional, participativa [...]",34 por esta lógica, o procedimento administrativo concertado dentro da perspectiva de tutela sanitária no SUS se abre como um canal de diálogo e consenso, podendo dele resultar - ainda que em última instância o ato administrativo seja unilateral - decisões democráticas e com níveis de aceitação social e legitimação positivos.

Eurico Bitencourt Neto, indo além, ensina que a concertação, numa concepção alargada, diz respeito às variadas relações entre o Estado e a sociedade que são marcadas pela negociação e pelo acordo, buscando, no Estado de Direito Democrático Social, analisar as pretensões sob a ótica do Direito Público, conformando interesses individuais com o interesse coletivo. ${ }^{35}$

Diante disso, atos podem ser praticados na gestão de conflitos no SUS, por negociações e acordos, satisfazendo, sempre que possível, as pretensões dos cidadãos, respeitando o direito fundamental à saúde, em suas vertentes objetiva e subjetiva, sem maiores gravames ao planejamento e execução da política pública de saúde.

Técnicas concertadas, no âmbito do SUS, são de extrema relevância e emergente necessidade, vez que podem agregar atores da prática dos serviços públicos de saúde, aumentando o diálogo e a proposição de resoluções coerentes para situações controversas, resgatando, ao final, a autonomia e sustentabilidade do SUS, pois como preceitua George Marmelstein Lima a proteção da autonomia do sistema consiste no fortalecimento das instâncias de deliberação internas, gerando o enfrentamento não somente da judicialização, mas também de interferências externas que o autor classifica como "influências espúrias", ${ }^{36}$ como o lobby da indústria farmacêutica, a título de exemplo.

As decisões, em sede de tutela administrativa sanitária, devem ser (b) resolutivas e vinculantes. Com relação à primeira característica, a resolutividade da decisão, busca-se indicar que, ao acatamento da solicitação feita pelo cidadão ou pelo gestor público, o parecer do órgão tutelador deve atacar o mérito da demanda, reconhecendo a controvérsia e decidindo, deferindo a pretensão, caso em que o direito à saúde estiver sendo violado ou, na medida do possível, em que o dito direito possa ser protegido nos termos do pedido de tutela, sem comprometer a (1) dimensão objetiva dos direitos fundamentais, que gera um dever de implementação coletiva; (2) a legislação sanitária;

34 BITENCOURT NETO, Eurico. Transformações do Estado e a Administração Pública no século XXI. Revista de Investigações Constitucionais, Curitiba, vol. 4, n. 1, p. 212, jan./abr. 2017. Disponível em: <https://revistas. ufpr.br/rinc/article/view/49773/31680>. Acesso em: 01 nov. 2018.

35 BITENCOURT NETO, Eurico. A Administração Pública concertada. In: A prevenção da corrupção e outros desafios à boa governação da Administração Pública. GOMES, Carla Amado; NEVES, Ana Fernanda; BITENCOURT NETO, Eurico (Coords). Lisboa: Centro de Investigação de Direito Público, 2017, p. 17.

36 LIMA, George Marmelstein. You can't always get what you want: repensando a judicialização da saúde com base no fornecimento de medicamentos. Revista de informação legislativa: RIL, vol. 54, n. 216, p. 108-109, out./dez. 2017. Disponível em: <http://www12.senado.leg.br/ril/edicoes/54/216/ril_v54_n216_p105>. Acesso em: 02 nov. 2018. 
e (3) autonomia do SUS; ou indeferindo, caso seja detectada desconformidade com os requisitos mencionados.

Com relação à vinculação, é de se destacar que esta busca, no âmbito da tutela sanitária, proteger os cidadãos de comportamentos contraditórios e, portanto, violadores da dignidade, igualdade e do dever de proteção da saúde, nos termos das diretrizes estabelecidas pela Constituição Federal de 1988 e a Lei no 8.080 de 1990.

O reconhecimento do caráter vinculante de precedentes em matéria administrativa já fora, substancialmente, tratado na doutrina brasileira com minúcia, ${ }^{37}$ conquanto, é relevante indicar as hipóteses que, na tutela sanitária, autorizam a mutação de orientação: i) superação do precedente por conta de interesse público, ou, nas palavras de Daniel Hachem, "caso exista motivação suficiente para mudar a orientação administrativa"; ${ }^{38}$ ii) anulação da decisão do órgão de tutela; e, por derradeiro, iii) a ilegalidade da decisão vinculante decorrente de fatores externos, não considerados ao tempo da análise administrativa.

\section{FUNDAMENTOS PARA A TUTELA ADMINISTRATIVA SANITÁRIA}

Afora detalhar o conceito da tutela administrativa sanitária e seus elementos, imperioso é explorar os fundamentos que justificam, no esteio do Estado de Direito democrático social, a institucionalização de tal forma de proteção do direito à saúde, sendo eles a (1) dignidade humana, o (2) princípio da eficiência sanitária, o (3) direito à boa administração e as (4) disposições de tratados internacionais de direitos humanos ratificados pelo Brasil, no âmbito dos Sistemas Global e Interamericano.

A (1) dignidade humana é um dos fundamentos do Estado brasileiro (art. 10, III, CF/88), funcionando como razão de ser e, ao mesmo tempo, como orientação da atuação estatal na persecução do interesse público. Antes de ostentar um caráter jurídico, a dignidade humana é, sobretudo, um valor, uma formulação axiológica ligada

\footnotetext{
37 Cf.: ARAGÃO, Alexandre Santos de. Teoria das autolimitações administrativas: atos próprios, confiança legítima e contradição entre órgãos administrativos. Revista Eletrônica de Direito Administrativo Econômico (REDAE), no 14, 2008. Disponível em: <www.direitodoestado.com/revista/REDAE-14-MAIO-2008-ALEXANDRE\%20ARAGAO.pdf>. Acesso em: 15 nov. 2018.; CARVALHO, Gustavo Carvalho de. Precedentes administrativos no direito brasileiro. São Paulo: Editora Contracorrente, 2015.; OLIVEIRA, Rafael Carvalho Rezende. Precedentes no direito administrativo. São Paulo: Grupo Editorial Nacional - GEN, 2018.; HACHEM, Daniel Wunder. Vinculação da Administração Pública aos precedentes administrativos e judiciais: mecanismo de tutela igualitária dos direitos sociais. A\&C - Revista de Direito Administrativo \& Constitucional, vol. 15, n. 59, p. 63-91, jan./mar. 2015. Disponível em: < http://www.revistaaec.com/index.php/revistaaec/article/view/64>. Acesso em: 15 nov. 2018.

38 HACHEM, Daniel Wunder. Vinculação da Administração Pública aos precedentes administrativos e judiciais: mecanismo de tutela igualitária dos direitos sociais. A\&C - Revista de Direito Administrativo \& Constitucional, vol. 15, n. 59, p. 72, jan./mar. 2015. Disponível em: <http://www.revistaaec.com/index.php/revistaaec/ article/view/64>. Acesso em: 15 nov. 2018.
} 
às percepções de justiça, bondade e plenitude. ${ }^{39}$ Guarda, em seu núcleo, o reconhecimento do ser humano como criatura distinta, devendo ser protegido em todas as suas dimensões: física, psicológica e social.

Nesse rumo, Lígia Melo de Casimiro assevera que a própria Constituição se orienta pelo princípio da dignidade humana, "[...] sendo o indivíduo e a promoção de seus direitos finalidades primeiras, e o Estado-administração um instrumento para o alcance desse fim".40 A Administração Pública deve agir, vinculada à dignidade, incessantemente para a garantia de direitos.

Inserida no plano jurídico, a dignidade humana passa ser concebida, pelo menos para boa parte da doutrina brasileira, como um princípio do Direito, gozando de caráter prima facie e, neste contexto, impõe o dever de não violação da integridade dos indivíduos. José Cretella Júnior afirma que "princípio é, antes de tudo, um ponto de partida", ${ }^{41}$ proposições basilares do Direito. Assim, pode-se perceber que o resguardo jurídico da integridade dos cidadãos, de todas as garantias fundamentais que a constituam, gera a obrigação da prestação de serviços públicos adequados, de forma universal, igualitária e suficiente.

A dignidade humana vincula a Administração Pública, que deve prestar serviços públicos condizentes com a sua proteção e realização, é o que ensina Adriana Schier. ${ }^{42}$ Para tanto, a atuação administrativa deve preocupar-se com a adequação dos serviços públicos de saúde e a necessidade de tutela interna.

Todavia, urge revelar que existe posicionamento divergente acerca da classificação da natureza jurídica da dignidade. Com afinco, Maria Sylvia Zanella Di Pietro ${ }^{43}$ declara que a dignidade humana pode ser compreendida, na forma disposta na Constituição de 1988, como valor, princípio ou regra. No Preâmbulo, está definida abstratamente enquanto um valor ideal a ser alcançado; no art. $1^{\circ}$, tem-se como princípio inerente ao Estado; e como base de diversas normas constitucionais, estas do tipo regra. Informa que a dignidade humana pode ser tida na qualidade de princípio e, igualmente, como regra, encerrando valor superlativo do Estado Democrático de Direito.

39 BARROSO, Luís Roberto. A dignidade da pessoa humana no direito constitucional contemporâneo: a construção de um conceito jurídico à luz da jurisprudência mundial. 3. Ed. Belo Horizonte: Editora Fórum, 2014.

40 CASIMIRO, Lígia Maria Silva Melo de. Novas perspectivas para o direito administrativo: a função administrativa dialogando com a juridicidade e os direitos fundamentais sociais. Revista de Direito Administrativo \& Constitucional, n. 30, p. 116, out/dez, 2007.

41 CRETELLA JÚNIOR, José. Os cânones do direito administrativo. Revista de Informação Legislativa, vol. 25, n. 97, p. 7, jan./mar. 1988. Disponível em: <http://www2.senado.leg.br/bdsf/item/id/181819>. Acesso em: 28 nov. 2018.

42 SCHIER, Adriana da Costa Ricardo. Serviço público: garantia fundamental e cláusula de proibição de retrocesso social. Curitiba: Íthala, 2016, p. 189-191.

43 DI PIETRO, Maria Sylvia Zanella. Direito administrativo e dignidade da pessoa humana. A\&C - Revista de Direito Administrativo \& Constitucional, vol. 13, n. 52, p. 19-20, abr./jun. 2013. Disponível em: <http://www. revistaaec.com/index.php/revistaaec/article/view/131>. Acesso em: 28 nov. 2018. 
Aproxima-se, aqui, do entendimento de Maria Sylvia Zanella Di Pietro, para fazer uma interpretação da dignidade, enquanto fundamento do direito à saúde, como uma regra. Ora, o art. $6^{\circ}$ prevê o direito à saúde como um direito social e, posteriormente no artigo 196, preconiza que a saúde é direito de todos e dever do Estado, que carece agir mediante políticas sociais e econômicas. A regra da dignidade humana, no esteio da saúde, é a proteção.

Por isso, sob a ótica da judicialização da saúde, a dignidade humana é violada em suas duas naturezas: princípio e regra. Primeiro, a integridade dos cidadãos fragmenta-se na medida em que o acesso aos serviços e ações de saúde não é igualitário e universal. Segundo, as regras que instrumentalizam a política pública de saúde, estando nelas inclusa implicitamente a "regra dignidade", são abandonadas.

Pelo evidenciado, a tutela administrativa sanitária pretende salvaguardar a dignidade humana em suas acepções. É verdadeira alternativa para superação de um “[...] avanço da Constituição [que] não foi suficiente para garantir a aplicação do princípio para expressiva parcela da população" ${ }^{44}$

Ademais, a dignidade humana, como trava-mestra do Direito administrativo contemporâneo, permeado pelo fenômeno da constitucionalização, autoriza que se configure no Brasil uma administração estatal dialógica e mais próxima dos cidadãos, rompendo com a visão tradicional da Administração Pública baseada na verticalização e na legalidade estrita. Diversamente, José Sérgio da Silva Cristóvam explica que tal mudança de paradigma ocorre "não por qualquer irresponsável ou pouco ilustrada doutrina de simples abandono daquele modelo, mas por uma profunda e radical revisão da sua lógica conceitual e dos seus limites operacionais e normativos".45

Insta salientar, por fim, que a dignidade humana, enquanto princípio autorizador de modificações na Administração Pública para a proteção do direito à saúde, não permite comportamentos livres, numa acepção ampla do termo. Do oposto, a liberdade para inovar e tutelar o direito à saúde encontra limites na Constituição e nos princípios que regem a atividade administrativa, inseridos no art. 37.

Em outra ponta, o princípio da eficiência está ligado à noção de uma administração gerencial, voltada para o alcance dos fins constitucionais de forma maximizada. A eficiência, enquanto mandamento principiológico, ganha relevância no contexto do Estado social, entretanto, causa grandes problemáticas com relação à sua "indeterminação", não existindo um conceito fechado sobre o que seria a eficiência na perspectiva

44 DI PIETRO, Maria Sylvia Zanella. Direito administrativo e dignidade da pessoa humana. A\&C - Revista de Direito Administrativo \& Constitucional, vol. 13, n. 52, p. 21, abr./jun. 2013. Disponível em: <http://www. revistaaec.com/index.php/revistaaec/article/view/131>. Acesso em: 28 nov. 2018.

45 CRISTÓVAM, José Sérgio da Silva. A dignidade da pessoa humana como princípio constitucional estruturante do direito administrativo. Revista jurídica da Procuradoria-Geral do Distrito Federal, vol. 40, n 1, p. 17, jan/jun., 2015. Disponível em: <https://revista.esmesc.org.br/re/article/view/122>. Acesso em: 28 nov. 2018. 
do Estado de Direito democrático social..$^{46}$ É preciso revelar, sem adentrar no mérito da possível dificuldade de determinação do seu conteúdo jurídico, que tal princípio possui um aspecto pluridimensional.

José Carlos Simões Loureiro ${ }^{47}$ explica que, no plano da indeterminação e pluralidade, a eficiência pode ser enfrentada pelos prismas da eficácia, otimização, celeridade e economia. Emerson Gabardo ${ }^{48}$ indica, por sua vez, que a eficiência pode ser analisada sob as dimensões da racionalidade, da produtividade, da celeridade e da economicidade. Já Alexandre Santos de Aragão, mais direto, conceitua a eficiência como"um melhor exercício das missões de interesse coletivo que incumbe ao Estado".49

Mesmo como um princípio indeterminado, Raquel Cavalcanti Ramos Machado ${ }^{50}$ delineia sua essência como o ato de perseguir resultados excelentes, na via administrativa, utilizando-se de potencialização temporal e qualificação das ferramentas empregues. Interessa para este estudo a noção de "qualidade dos meios empregados". Romeu Felipe Bacellar Filho ${ }^{51}$ ensina que é necessário adequar o conteúdo dos princípios a partir de parâmetros constitucionalmente definidos. Dito isso, aplicando a técnica da adequação, associando a qualidade de meios - como integrante do dito princípio - aos artigos $6^{\circ}$ e 196 , tem-se a eficiência sanitária enquanto uma das dimensões da eficiência.

A (2) eficiência sanitária deve ser entendida, substancialmente, como faceta do princípio da eficiência que autoriza a Administração Pública, na garantia e proteção de direitos, adotar meios capazes e indispensáveis para a democratização, universalização e efetividade das ações e serviços prestados pelo Sistema Único de Saúde - SUS, devendo agir de maneira simplificada para, diante das demandas sociais que implicam em uma judicialização excessiva e na tutela desigual da saúde, atingir os fins constitucionalmente definidos com a melhor qualidade possível.

Uma noção, no mínimo equivocada, da supremacia do interesse público permitiu uma interpretação da eficiência que conferisse ao Estado "prerrogativas" para a persecução de seus "objetivos", muito embora a mesma interpretação não se aplique em

46 Para uma proposta conceitual nesse sentido, ver: HACHEM, Daniel Wunder; GABARDO, Emerson. El principio constitucional de eficiencia administrativa: contenido normativo y consecuencias jurídicas de su violación. Cuestiones Constitucionales: Revista Mexicana de Derecho Constitucional, n. 39, p. 131-167, jul. /dic. 2018.

47 LOUREIRO, José Carlos Simões. O procedimento administrativo entre a eficiência e a garantia dos particulares: algumas considerações. Coimbra: Boletim da Faculdade de Direito de Coimbra, 2015.

48 GABARDO, Emerson. Princípio constitucional da eficiência administrativa. São Paulo: Dialética, 2002, p. 27-30.

49 ARAGÃO, Alexandre Santos de. O princípio da eficiência. Revista de Direito Administrativo, Rio de Janeiro, vol. 237, p. 1, jul. 2004. Disponível em: <http://bibliotecadigital.fgv.br/ojs/index.php/rda/article/view/44361>. Acesso em: 09 dez. 2018.

50 MACHADO, Raquel Cavalcanti Ramos. Eficiência administrativa e dignidade do cidadão. In: MELO, Felipe Reis; MENDONÇA, Maria L. C. de Araújo; SCHNEIDER, Yuri (Coords.). Direito e Administração Pública II. Florianópolis: CONPEDI, 2014, p. 154.

51 BACELLAR FILHO, Romeu Felipe Bacellar. Princípios constitucionais do processo administrativo disciplinar. São Paulo: Max Limonad, 1998, 193-197. 
benefício do cidadão. ${ }^{52}$ Todavia, Raquel Machado ensina que em resposta ao princípio da eficiência a Administração tem procurado concretizar instrumentos que viabilizem suas atividades, mas isso não gera otimização no que diz respeito aos serviços públicos prestados. ${ }^{53}$ Por esse ângulo, concebe-se a eficiência sanitária como norma constitucional principiológica implícita, a ser aplicada em favor dos cidadãos usuários do sistema público de saúde, como fundamento para a tutela administrativa em matéria de saúde, a gerar impactos positivos na vida dos cidadãos brasileiros.

O (3) direito fundamental à boa administração está, historicamente, vinculado à Carta dos Direitos Fundamentais da União Europeia de $2000 .{ }^{54}$ A Carta de Nice reconheceu, no artigo 41, o direito à boa administração, em um movimento eivado de significados e de compromissos com a proteção e segurança dos direitos e liberdades dos indivíduos. Vanice Lírio do Valle ${ }^{55}$ explica que este fenômeno ocorreu, sobretudo, por influência da "tradição constitucional de importantes Estados-Membros no sentido da proteção a direitos fundamentais e a reverência à centralidade da pessoa, nos compromissos constitucionais de países reconstitucionalizados ao final do século XX."

Apesar de a Carta de Nice representar, mundialmente, um marco na positivação do direito à boa administração, isso não significa que tal direito não constasse no ordenamento jurídico brasileiro, ainda que implicitamente. A Constituição de 88, caracteristicamente democrática e social, já surge ladeada pela noção do direito à boa administração. Em vários pontos revela, sem confusões, que a preocupação constituinte se dirigiu a preservação do bom funcionamento do Estado e de seu aparato administrativo. Os fundamentos e objetivos da República (arts. $1^{\circ}$ e $3^{\circ}$ ), os direitos e garantias individuais e sociais (arts. $5^{\circ}$ e $6^{\circ}$ ), a previsão de controles interno e externo (art. 70), bem

52 Sobre o referido princípio, ver: GABARDO, Emerson. O princípio da supremacia do interesse público sobre o interesse privado como fundamento do Direito Administrativo Social. Revista de Investigações Constitucionais, Curitiba, v. 4, n. 2, p. 95-130, maio/ago. 2017. Disponível em: <https://revistas.ufpr.br/rinc/article/ view/53437/33212>. Acesso em: 10 dez. 2018.

53 MACHADO, Raquel Cavalcanti Ramos. Eficiência administrativa e dignidade do cidadão. In: MELO, Felipe Reis; MENDONÇA, Maria L. C. de Araújo; SCHNEIDER, Yuri (Coords.). Direito e Administração Pública II. Florianópolis: CONPEDI, 2014, p. 146.

54 HACHEM, Daniel; VALENCIA-TELLO, Diana Carolina. Reflexiones sobre el derecho fundamental a la buena administración pública en el derecho administrativo brasilero, Revista digital de Derecho Administrativo, n. ${ }^{\circ}$ 21, 2019, p. 50. Disponível em: <https://revistas.uexternado.edu.co/index.php/Deradm/article/view/5700>. Acesso em: 10 dez. 2018; VALENCIA-TELLO, Diana Carolina; HACHEM, Daniel. La buena administración pública en el siglo XXI: análisis del caso colombiano. Veredas do Direito, Belo Horizonte, v.15, n.33, p.101-130, set./dez. 2018. Disponível em: <http://revista.domhelder.edu.br/index.php/veredas/article/view/1326>. Acesso em: 10 dez. 2018.

55 VALLE, Vanice Regina Lírio do. Direito fundamental à boa administração e governança: democratizando a função administrativa. 2010. 254 f. Tese (Doutorado) - Curso de Pós-doutorado em Administração, Escola Brasileira de Administração Pública e de Empresas, Fundação Getúlio Vargas, Rio de Janeiro, 2010, p. 109. Disponível em: <http://bibliotecadigital.fgv.br/dspace/bitstream/handle/10438/6977/VANICE\%20VALLE. pdf? sequence=1\&isAllowed=y $>$. Acesso em: 10 dez. 2018. 
como a expressa cláusula de adequação dos serviços públicos (art. 175, IV) constituem verdadeiros corolários do direito fundamental então discutido.

Juarez Freitas, ${ }^{56}$ em sua obra, explicita que a obrigação irrecusável de uma boa administração constitui direito fundamental, que vincula a atuação do administrador à totalidade de princípios dispostos na Constituição de 1988. Nota-se, pois, que o direito à boa administração alberga uma variedade de outros direitos, explícitos e implícitos na Constituição e na legislação infraconstitucional. Se, por um lado, parece espinhoso a delimitação medular de tal direito, de outro, é factível perceber sua pluridimensionalidade.

Por outra ocasião, Juarez Freitas ${ }^{57}$ prenuncia que no conceito desenhado encontram-se os direitos “[...] à administração pública sustentável [...], dialógica [...], preventiva, precavida e eficaz [...]". Assim sendo, o direito à boa administração é base notável da tutela administrativa sanitária, vez que esta busca criar, na seara do SUS e da concreção do direito à saúde, o acesso universal, igualitário e integral, nos termos da Lei no 8.080 de 1990 e da própria Constituição.

A boa administração é, no âmbito do Sistema Único de Saúde, alicerce para a construção de práticas cooperativas e abertas, devendo o Estado sanitário, pela polissemia do direito à saúde, estar aberto para ouvir as demandas dos cidadãos e, posteriormente, contemplar "[...] a necessidade de concretização de um direito fundamental social, baseado no princípio da fraternidade, que implica na necessidade de ir além, muitas vezes, do direito individual para garantir o direito de todos". ${ }^{\prime 8}$

O direito à boa administração espelha, ainda, no contexto do sistema público de saúde, instrumento de (i) equilíbrio entre os mandamentos constitucionais de igualdade e liberdade; (ii) de reconhecimento de pretensões dentro das possibilidades estatais; (iii) de desconstrução de paradoxos, firmando uma gestão de saúde com caráter protetivo; e, por último, (iv) de proteção da cidadania.

Acerca do Direito Internacional dos Direitos Humanos, Antonio Caçando Trinda$\mathrm{de}^{59}$ clarifica que sua fonte material repousa sobre a ideia universal da proteção jurídica dos seres humanos. Explica, igualmente, que num plano de organização, os (4) tratados podem ser enquadrados dentro dos sistemas global e regional de proteção, contando

\footnotetext{
56 FREITAS, Juarez. Discricionariedade administrativa e o direito fundamental à boa administração pública. São Paulo: Malheiros, 2007, p. 20.

57 FREITAS, Juarez. As políticas públicas e o direito fundamental à boa administração pública. NOMOS, Revista do Programa de Pós-graduação da UFC, vol. 35, n. 01, jan/jul., 2015, p. 198-199. Disponível em: <http:// www.periodicos.ufc.br/nomos/article/view/2079/1555>. Acesso em: 10 dez. 2018.

58 MARTINI, Sandra Regina; MACHADO, Clara. Desjudicialização da saúde, diálogos interinstitucionais e participação social: em busca de alternativas para o sistema. Revista de Estudos Institucionais, vol. 04, n. 2, p. 779 , 2018. Disponível em: <https://estudosinstitucionais.com/REl/article/view/190>. Acesso em: 10 nov. 2018.

59 TRINDADE, Antônio Augusto Cançado. Tratado de direito internacional dos direitos humanos. 2. Ed. Porto Alegre: Sergio Antonio Fabris Editor, 2003, p. 37.
} 
com uma estruturação bem delineada, havendo, do mesmo modo, instrumentos de garantia de tais documentos.

A hierarquia dos tratados internacionais de direitos humanos causa controvérsia no Direito pátrio. O Supremo Tribunal Federal - STF, até 2008, sustentou a tese da legalidade dos tratados. Tal entendimento foi superado, por ocasião do julgamento do Recurso Extraordinário n 466-343/SP, firmando-se a tese de que os tratados de direitos humanos ostentam feição de supralegalidade, mas sem embargos, o tratado submetido ao procedimento do art. $5^{\circ}, \S 3$, inserido na Constituição pela Emenda Constitucional nº 45/2004, receberá índole constitucional. ${ }^{60}$

Felipe Klein Gussoli, noutro entender, defende o caráter supraconstitucional dos tratados humanísticos, ${ }^{61}$ ou seja, para o autor as disposições internacionais merecem local de superioridade com relação à Constituição. No mesmo sentido é a percepção de Celso Duvivier de Albuquerque Mello, ${ }^{62}$ para quem a norma internacional sempre prevalece sobre a constitucional, não podendo ser sequer ser revogada.

Ainda há um outro posicionamento, com maior aceitação na doutrina brasileira, que pugna pela constitucionalidade dos tratados, tendo em vista o $\S 2{ }^{\circ}$, do art. $5^{\circ}$, da Constituição. Valério Mazzuoli ${ }^{63}$ pontua que "[...] segue a tendência do constitucionalismo contemporâneo, sempre defendemos que os tratados internacionais de direitos humanos ratificados pelo Brasil têm índole e nível constitucionais."

Em que pese os diversos posicionamentos e o conflito entre a doutrina e a jurisprudência brasileiras, aproxima-se nesta pesquisa da tese de supraconstitucionalidade dos tratados internacionais de direitos humanos, pois há, sem questionamentos, maior proteção a direitos e garantias individuais e sociais, protegendo-os inclusive contra potencial retrocesso do Direito interno. Felipe Gussoli, de modo adequado, informa que o Direito interno e o Direito internacional dos direitos humanos estão alinhados por conta das normas desenhadas na Constituição brasileira, ${ }^{64}$ da cláusula de abertura material.

Urge destacar que alguns tratados de direitos humanos que o Brasil ratifica fazem previsão expressa do direito à saúde e sua proteção, são eles: Pacto Internacional dos Direitos Econômicos, Sociais e Culturais (1966), Convenção Americana de Direitos Humanos - Pacto de San José da Costa Rica (1969) e o Protocolo Adicional à Convenção

60 PIOVESAN, Flávia. Direitos humanos e o direito constitucional internacional. 18. Ed. rev. e atual. São Paulo: Saraiva, 2018.

61 GUSSOLI, Felipe Klein. Hierarquia supraconstitucional relativa dos tratados internacionais de direitos humanos. Revista de Investigações Constitucionais, Curitiba, vol. 6, n. 3, p. 703-747, set./dez. 2019.

62 MELLO, Celso D. de Albuquerque. O § $2^{\circ}$ do art. $5^{\circ}$ da Constituição Federal. In: TORRES, Ricardo Lobo (Org.). Teoria dos direitos fundamentais. 2. Ed. Rio de Janeiro: Renovar, 2001, p. 2-29.

63 MAZUOLLI, Valerio de Oliveira. O controle jurisdicional de convencionalidade das leis. 2. Ed. São Paulo: Revista dos Tribunais, 2011, p. 28.

64 GUSSOLI, Felipe Klein. Impactos dos tratados internacionais de direitos humanos no direito administrativo brasileiro. 2018. 329 f. Dissertação (Mestrado) - Curso de Mestrado em Direito, Escola de Direito, Pontifícia Universidade Católica do Paraná, Curitiba, 2018, p. 41. 
Americana sobre Direitos Humanos em matéria de Direitos Econômicos, Sociais e Culturais (1988).

O Pacto Internacional dos Direitos Econômicos, Sociais e Culturais (1966), no artigo 12, declara: "os Estados Partes do presente Pacto reconhecem o direito de toda pessoa de desfrutar o mais elevado nível possível de saúde física e mental", ${ }^{65}$ o item 2, do refiro artigo, complementa afirmando que os Estados-partes deverão adotar as medidas necessárias para assegurar tal direito.

A Convenção Americana de Direito Humanos (1969), no artigo 26, estipula que os Estados-parte são obrigados a comprometerem-se e adotarem normas que busquem, na medida do possível, a implementação de direitos que decorrem de normas sociais. ${ }^{66}$

O Protocolo Adicional à Convenção Americana sobre Direitos Humanos em matéria de Direitos Econômicos, Sociais e Culturais (1988), no artigo 10, assinala: "toda pessoa tem direito à saúde, entendida como o gozo do mais alto nível de bem-estar físico, mental e social", ${ }^{67}$ devendo ainda os Estados a reconhecerem como bem público.

Considerando a configuração supraconstitucional dos Tratados citados, de modo particular no que se refere à saúde, é coerente a percepção de que, além de imporem à Administração Pública brasileira o dever de efetivação de tal direito, os Tratados Internacionais de Direitos Humanos estimulam e legitimam a atuação administrativa criativa, cooperativa e dialógica, no sentido de contemplar novas formas de resolução de conflitos sanitários e proteção da saúde, para assim diminuir a judicialização e seus impactos.

\section{CONCLUSÃO}

A conformação do direito à saúde constitui solo copioso para o surgimento de conflitos. Sem dúvidas, nos últimos anos, o Sistema Único de Saúde - SUS, enquanto política pública, tem sido afetado pela judicialização excessiva, que altera, reconfigura e redireciona os rumos do sistema desenhados pela Constituição de 1988 e pela Lei no 8.080/1990.

65 ORGANIZAÇÃO DAS NAÇÕES UNIDAS. Pacto internacional dos direitos econômicos, sociais e culturais. 1966, p. 01. Disponível em: <https://nacoesunidas.org/?post_type=post\&s=PACTO+INTERNACIONAL+DIREITOS+ECONOMICOS+SOCIAIS+E+CULTURAIS>. Acesso em: 11 dez. 2018.

66 COMISSÃO INTERAMERICANA DE DIREITOS HUMANOS. Convenção Americana de Direitos Humanos. 1969. Disponível em: <https://www.cidh.oas.org/basicos/portugues/c.convencao_americana.htm>. Acesso em: 11 dez. 2018.

67 COMISSÃO INTERAMERICANA DE DIREITOS HUMANOS. Protocolo adicional à Convenção Americana sobre Direitos Humanos em matéria de Direitos Econômicos, Sociais e Culturais, "Protocolo de San Salvador". 1988, p. 01. Disponível em: <http://www.cidh.org/Basicos/Portugues/e.Protocolo_de_San_Salvador. htm>. Acesso: $11 \mathrm{dez} .2018$. 
Dessa forma, o Poder Judiciário passa a atuar como uma outra via de acesso ao direito à saúde e, por decorrência de limitações da capacidade institucional e pelo policentrismo dos problemas inerentes à política pública de saúde, há de se reconhecer a existência de um espaço aberto para decisões controversas, violadoras da universalidade e da igualdade no SUS.

Assim, é importante reconhecer que a Administração Pública, numa perspectiva juridicizante, deve atuar de modo criativo a garantir o direito à saúde, sobretudo o fornecimento de medicamentos, para os cidadãos brasileiros. Nesse cenário, falar em criatividade significa instituir procedimentos administrativos que permitam a avaliação e resolução de problemas resultantes da implementação da política pública ora discutida, desaguando em atos necessários para a proteção da saúde, equalizadores das dimensões objetivas e subjetivas.

Por essa conjectura, elabora-se uma ideia de tutela administrativa que não corresponde à possibilidade de fiscalização da Administração Indireta pela Direta, mas que se refere a uma noção de proteção administrativa procedimentalizada dentro do SUS. A tutela administrativa sanitária é concebida como o poder-dever administrativo que conduz à proteção da saúde, por intermédio da análise e avaliação de questões problemáticas envolvendo tal direito, numa lógica interna ao SUS.

A tutela sanitária sustenta-se na Constituição de 1988 e em suas disposições, especificamente na dignidade humana, na eficiência sanitária, no direito à boa administração, bem como encontra guarida nos Tratados internacionais de direitos humanos ratificados pelo Brasil.

A prática da tutela, nos termos elaborado neste trabalho, poderá contribuir para (i) o aumento do protagonismo da Administração Pública no âmbito do direito à saúde e do SUS, sobretudo na questão do fornecimento de medicamentos, que possui um fluxo de mudanças dinâmico; (ii) legitimar as decisões administrativas pelo fornecimento ou não de determinado tratamento, vez que haverá verificação dos limites clínicos, jurídicos, orçamentários e sociais do pleito formulado pelo cidadão; (iii) o equilíbrio das dimensões objetiva e subjetivas do direito à saúde; (iv) reforçar a estrutura e a autonomia do Sistema Único de Saúde - SUS, elidindo decisões contrárias às diretrizes de universalidade e igualdade; (v) criação de uma cultura do diálogo e do exercício da cidadania; e, por último, (vi) contribuir para o processo de desjudicialização do SUS.

\section{REFERÊNCIAS}

ARAGÃO, Alexandre Santos de. Curso de direito administrativo. 2. Ed. Rio de Janeiro: Forense, 2013. 
ARAGÃO, Alexandre Santos de. O princípio da eficiência. Revista de Direito Administrativo, Rio de Janeiro, vol. 237, p. 1-6, jul. 2004. Disponível em: <http://bibliotecadigital.fgv.br/ojs/index.php/ rda/article/view/44361 $\geq$. Acesso em: 09 dez. 2018.

ÁVILA, Ana Paula Oliveira; MELO, Karen Cristina Correa de. Separação de poderes e diálogos institucionais nos litígios envolvendo o direito à saúde. Revista de Investigações Constitucionais, vol. 5, n. 1, p.83-108, 1 jan. 2018. Disponível em: <https://revistas.ufpr.br/rinc/ article/view/54934/35005>. Acesso em: 26 nov. 2019.

BACELLAR FILHO, Romeu Felipe. Princípios constitucionais do processo administrativo disciplinar. São Paulo: Max Limonad, 1998.

BARBERATO, Celso; GERAIDE NETO, Zaiden. O direito à saúde no contexto do neoconstitucionalismo. Nomos: Revista do Programa de Pós-graduação em Direito da UFC, p.107-126, dez. 2014. Semestral. Disponível em: <http://periodicos.ufc.br/nomos/article/view/1217 . Acesso em: 15 set. 2018.

BARROSO, Luís Roberto. A dignidade da pessoa humana no direito constitucional contemporâneo: a construção de um conceito jurídico à luz da jurisprudência mundial. 3. Ed. Belo Horizonte: Editora Fórum, 2014.

BERTOTTI, Bárbara Mendonça; PIVETTA, Saulo Lindorfer. A integração da iniciativa privada ao sistema público de saúde brasileiro: limites e possibilidades. Revista Eurolatinoamericana de Derecho Administrativo, Santa Fe, vol. 5, n. 2, p. 239-265, jul./dic. 2018.

BITENCOURT NETO, Eurico. A Administração Pública concertada. In: A prevenção da corrupção e outros desafios à boa governação da Administração Pública. GOMES, Carla Amado; NEVES, Ana Fernanda; BITENCOURT NETO, Eurico (Coords). Lisboa: Centro de Investigação de Direito Público, 2017.

BITENCOURT NETO, Eurico. Transformações do Estado e a Administração Pública no século XXI. Revista de Investigações Constitucionais, vol. 4, n. 1, p. 207-225, jan./abr. 2017. Disponível em: $<$ https://revistas.ufpr.br/rinc/article/view/49773/31680 . Acesso em: 01 nov. 2018.

BRASIL. Portaria de Consolidação no 1, de 28 de setembro de 2018. Consolidação das normas sobre os direitos e deveres dos usuários da saúde, a organização e o funcionamento do Sistema Único de Saúde. Diário Oficial da União, Brasília, DF, 28 de set. de 2017. Disponível em: <http:// bvsms.saude.gov.br/bvs/saudelegis/gm/2017/prc0001_03_10_2017_comp.html>. Acesso em: 16 out. 2018

BRASIL. Siga Brasil. Senado Federal. Siga Brasil painéis: Orçamento Federal. 2018. Disponível em: <https://www12.senado.leg.br/orcamento/sigabrasil>. Acesso em: 20 out. 2018.

CAMBI, Eduardo; VASCONCELOS, João Paulo A. Desjudicialização de políticas públicas e o Novo Código de Processo Civil - Contributo do Ministério Público e da Advocacia Pública à solução 
extrajudicial de conflitos. A\&C - Revista de Direito Administrativo \& Constitucional, Belo Horizonte, ano 16, n. 64, p. 225-251, abr./jun. 2016.

CARVALHO, Osvaldo Ferreira de. As políticas públicas como concretização dos direitos sociais. Revista de Investigações Constitucionais, Curitiba, vol. 6, n. 3, p. 773-794, set./dez. 2019. Disponível em: <https://revistas.ufpr.br/rinc/article/view/59730/40602 . Acesso em: 05 dez. 2019.

CASIMIRO, Lígia Maria Silva Melo de. A participação social no planejamento das políticas públicas urbanas. Revista Eurolatinoamericana de Derecho Administrativo, Santa Fe, vol. 4, n. 1, p. 7-21, ene./jun. 2017.

CASIMIRO, Lígia Maria Silva Melo de. Novas perspectivas para o direito administrativo: a função administrativa dialogando com a juridicidade e os direitos fundamentais sociais. A\&C - Revista de Direito Administrativo \& Constitucional, n. 30, p. 109-130, out/dez, 2007.

CASIMIRO, Ligia Maria Silva Melo; MORAES, Filomeno. Planejamento social na Administração Pública: um instrumento essencial na promoção dos direitos fundamentais sociais. Revista de Direito Econômico e Socioambiental, Curitiba, v. 8, n. 2, p. 443-461, maio/ago. 2017.

CASSESE, Sabino. Le trasnformazioni del diritto amministrativo dal XIX al XXI secolo. Rivista trimestrale di diritto pubblico, vol. 1, p. 27-40, 2002.

COMISSÃO INTERAMERICANA DE DIREITOS HUMANOS. Convenção Americana de Direitos Humanos. 1969. Disponível em: <https://www.cidh.oas.org/basicos/portugues/c.convencao_americana.htm>. Acesso em: 11 dez. 2018.

COMISSÃO INTERAMERICANA DE DIREITOS HUMANOS. Protocolo adicional à Convenção Americana sobre Direitos Humanos em matéria de Direitos Econômicos, Sociais e Culturais, “Protocolo de San Salvador". 1988. Disponível em: <http://www.cidh.org/Basicos/Portugues/e. Protocolo_de_San_Salvador.htm $\geq$ Acesso: 11 dez. 2018.

CRETELLA JÚNIOR, José. Definição da tutela administrativa. Revista de Direito Administrativo, Rio de Janeiro, vol. 96, p. 28-40, ago. 1969. Disponível em: <http://bibliotecadigital.fgv.br/ojs/index.php/rda/article/view/32209 . Acesso em: 05 set. 2018.

CRETELLA JÚNIOR, José. Os cânones do direito administrativo. Revista de Informação Legislativa, vol. 25, n. 97, p. 5-52, jan./mar. 1988. Disponível em: <http://www2.senado.leg.br/bdsf/item/ $\mathrm{id} / 181819 \geq$. Acesso em: 28 nov. 2018.

CRISTÓVAM, José Sérgio da Silva. A dignidade da pessoa humana como princípio constitucional estruturante do direito administrativo. Revista jurídica da Procuradoria-Geral do Distrito Federal, vol. 40, no 1, p. 13-34, jan/jun., 2015. Disponível em: <https://revista.esmesc.org.br/re/ article/view/122>. Acesso em: 28 nov. 2018.

DAL POZZO, Emerson Luís; MION, Ronaldo de Paula. Controle jurisdicional das políticas públicas de saúde através da inclusão de medicamentos na relação de medicamentos essenciais do 
Sistema Único de Saúde. A\&C - Revista de Direito Administrativo \& Constitucional, Belo Horizonte, ano 19, n. 77, p. 199-228, jul./set. 2019.

DEZAN, Sandro Lucio; BRASIL JÚNIOR, Samuel Meira. A juridicidade do Estado-administração na concretização de políticas públicas de saúde - Um método para a justificação da eficácia horizontal dos direitos fundamentais. A\&C - Revista de Direito Administrativo \& Constitucional, vol. 16, n. 63, p. 211-238, jan./mar. 2016. Disponível em: <http://www.revistaaec.com/index.php/

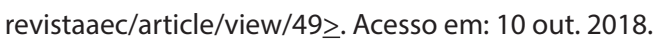

FREITAS, Juarez. As políticas públicas e o direito fundamental à boa administração pública. NOMOS, Revista do Programa de Pós-graduação da UFC, vol. 35, n. 01, jan/jul., 2015, p. 195-217. Disponível em: <http://www.periodicos.ufc.br/nomos/article/view/2079/1555 2 . Acesso em: 10 dez. 2018.

FREITAS, Juarez. Discricionariedade administrativa e o direito fundamental à boa administração pública. São Paulo: Malheiros, 2007.

GABARDO, Emerson. O princípio da supremacia do interesse público sobre o interesse privado como fundamento do Direito Administrativo Social. Revista de Investigações Constitucionais, Curitiba, v. 4, n. 2, p. 95-130, maio/ago. 2017. Disponível em: <https://revistas.ufpr.br/rinc/article/ view/53437/33212>. Acesso em: $10 \mathrm{dez} .2018$.

GABARDO, Emerson. Princípio constitucional da eficiência administrativa. São Paulo: Dialética, 2002.

GUSSOLI, Felipe Klein. Hierarquia supraconstitucional relativa dos tratados internacionais de direitos humanos. Revista de Investigações Constitucionais, Curitiba, vol. 6, n. 3, p. 703-747, set./ dez. 2019.

GUSSOLI, Felipe Klein. Impactos dos tratados internacionais de direitos humanos no direito administrativo brasileiro. 2018. 329 f. Dissertação (Mestrado) - Curso de Mestrado em Direito, Escola de Direito, Pontifícia Universidade Católica do Paraná, Curitiba, 2018.

HACHEM, Daniel Wunder. São os direitos sociais "direitos públicos subjetivos"? Mitos e confusões na teoria dos direitos fundamentais. Revista de Estudos Constitucionais, Hermenêutica e Teoria do Direito, São Leopoldo, v. 11, n. 3, p. 404-436, set./dez. 2019.

HACHEM, Daniel Wunder. Tutela administrativa efetiva dos direitos fundamentais sociais: por uma implementação espontânea, integral e igualitária. 2014. 625 f. Tese - Doutorado em Direito, Setor de Ciências Jurídicas - Programa de Pós-Graduação em Direito, Universidade Federal do Paraná - UFPR, Curitiba, 2014.

HACHEM, Daniel Wunder. Vinculação da Administração Pública aos precedentes administrativos e judiciais: mecanismo de tutela igualitária dos direitos sociais. A\&C - Revista de Direito Administrativo \& Constitucional, Belo Horizonte, ano 15, n. 59, p. 63-91, jan./mar. 2015. Disponível em: <http://www.revistaaec.com/index.php/revistaaec/article/view/64 . Acesso em: 15 nov. 2018. 
HACHEM, Daniel Wunder; GABARDO, Emerson. El principio constitucional de eficiencia administrativa: contenido normativo y consecuencias jurídicas de su violación. Cuestiones Constitucionales: Revista Mexicana de Derecho Constitucional, n. 39, p. 131-167, jul. /dic. 2018.

HACHEM, Daniel; VALENCIA-TELLO, Diana Carolina. Reflexiones sobre el derecho fundamental a la buena administración pública en el derecho administrativo brasilero, Revista digital de Derecho Administrativo, Universidad Externado de Colombia, n. ${ }^{\circ} 21$, 2019, pp. 47-75. Disponível em: $<$ https://revistas.uexternado.edu.co/index.php/Deradm/article/view/5700 $\geq$. Acesso em: $10 \mathrm{dez}$. 2018.

LIMA, George Marmelstein. You can't always get what you want: repensando a judicialização da saúde com base no fornecimento de medicamentos. Revista de informação legislativa: RIL, vol. 54, n. 216, p. 105-130, out./dez. 2017. Disponível em: <http://www12.senado.leg.br/ril/edicoes/54/216/ril_v54_n216_p105>. Acesso em: 02 nov. 2018.

LOUREIRO, José Carlos Simões. $\mathbf{O}$ procedimento administrativo entre a eficiência e a garantia dos particulares: algumas considerações. Coimbra: Boletim da Faculdade de Direito de Coimbra, 2015.

MACHADO, Raquel Cavalcanti Ramos. Eficiência administrativa e dignidade do cidadão. In: MELO, Felipe Reis; MENDONÇA, Maria L. C. de Araújo; SCHNEIDER, Yuri (Coords.). Direito e Administração Pública II. Florianópolis: CONPEDI, 2014.

MARIANO, Cynara Monteiro; FURTADO, Emanuel Teófilo; ALBUQUERQUE, Felipe Braga; PEREIRA Fabrícia Helena Linhares Coelho da Silva. Diálogos Sanitários Interinstitucionais e a experiência de implantação do NAT-JUS. Revista de Investigações Constitucionais, Curitiba, vol. 5, n. 1, p. 169-188, jan./abr. 2018. Disponível em: <https://revistas.ufpr.br/rinc/article/view/56027/35009>. Acesso em: 01 nov. 2018.

MARTINI, Sandra Regina; MACHADO, Clara. Desjudicialização da saúde, diálogos interinstitucionais e participação social: em busca de alternativas para o sistema. Revista de Estudos Institucionais, vol. 04, n. 2, p. 774-796, 2018. Disponível em: <https://estudosinstitucionais.com/REI/ article/view/190>. Acesso em: 10 nov. 2018.

MARTINS, Mary Anne Fontenele; GALATO, Dayani. Irregularidades dos medicamentos comercializados no Brasil: uma análise das notificações e das medidas sanitárias de 2012 a 2017. Vigilância Sanitária em Debate: sociedade, ciência e tecnologia, Rio de Janeiro, [s.l.], vol. 6, n. 4, p.23-33, 2018. Disponível em: <https://visaemdebate.incqs.fiocruz.br/index.php/visaemdebate/article/ view/1165 $\geq$. Acesso em: 02 set. 2018.

MAZUOLLI, Valério de Oliveira. $\mathbf{O}$ controle jurisdicional de convencionalidade das leis. 2. Ed. São Paulo: Revista dos Tribunais, 2011.

MEIRELLES, Hely Lopes. Direito administrativo brasileiro. 41. Ed. São Paulo: Malheiros Editores, 2014. 
MELLO, Celso D. de Albuquerque. O $§ 2^{\circ}$ do art. $5^{\circ}$ da Constituição Federal. In: TORRES, Ricardo Lobo (Org.). Teoria dos direitos fundamentais. 2. Ed. Rio de Janeiro: Renovar, 2001.

MEZZAROBA, Orides; SILVEIRA, Vladmir Oliveira da. The principle of the dignity of human person: $A$ reading of the effectiveness of citizenship and human rights through the challenges put forward by globalization. Revista de Investigações Constitucionais, Curitiba, vol. 5, n. 1, p. 273-293, jan./abr. 2018. Disponível em: <https://revistas.ufpr.br/rinc/article/view/54099/35013 2. Acesso em: 05 set. 2018.

OBSERVATÓRIO DE ANÁLISE POLÍTICA EM SAÚDE (BAHIA). Instituto de Saúde Coletiva da UFBA. Judicialização na saúde: panorama aponta aumento de $\mathbf{7 2 7 \%}$ nos gastos da União. 2017. Disponível em: <https://analisepoliticaemsaude.org/oaps/noticias/aefce52bac4b5a12668347eb6626c67f/>. Acesso em: 20 out. 2018.

ORGANIZAÇÃO DAS NAÇÕES UNIDAS. Pacto internacional dos direitos econômicos, sociais e culturais. 1966. Disponível em: <https://nacoesunidas.org/?post_type=post\&s=PACTO+INTERNACIONAL+DIREITOS+ECONOMICOS+SOCIAIS+E+CULTURAIS $\geq$. Acesso em: 11 dez. 2018.

PAMELA TENREYRO, María. Técnicas de tutela frente a la inactividad administrativa. Córdoba: Academia Nacional de Derecho y Ciências Sociales de Córdoba, 2012.

PEREIRA JÚNIOR, Jessé Torres. Presença da administração consensual no direito positivo brasileiro. In: MOREIRA NETO, Diogo de Figueiredo (Coord.). Uma avaliação das tendências contemporâneas do direito administrativo. Rio de Janeiro: Renovar, 2003.

PIETRO, Maria Sylvia Zanella Di. Direito administrativo. 31. Ed. Rio de Janeiro: Forense, 2018.

PIETRO, Maria Sylvia Zanella Di. Direito administrativo e dignidade da pessoa humana. A\&C - Revista de Direito Administrativo \& Constitucional, Belo Horizonte, ano 13, n. 52, p. 13-33, abr./ jun. 2013. Disponível em: <http://www.revistaaec.com/index.php/revistaaec/article/view/131>. Acesso em: 28 nov. 2018.

PIOVESAN, Flávia. Direitos humanos e o direito constitucional internacional. 18. Ed. rev. e atual. São Paulo: Saraiva, 2018.

PIVETTA, Saulo Lindorfer. Políticas públicas e a construção do conteúdo material do direito à saúde: desafio à Administração Pública brasileira. A\&C - Revista de Direito Administrativo \& Constitucional, Belo Horizonte, ano 10, n. 41, p. 209-230, jul./set. 2010.

SCHIER, Adriana da Costa Ricardo. Serviço público: garantia fundamental e cláusula de proibição de retrocesso social. Curitiba: Íthala, 2016.

SORENSEN, Georg. La transformación del Estado: mas allá del mito del repliegue. Trad. Ramón Cotarelo. Valencia: Tirant lo Blanch, 2010.

TRINDADE, Antônio Augusto Cançado. Tratado de direito internacional dos direitos humanos.

2. Ed. Porto Alegre: Sergio Antonio Fabris Editor, 2003. 
VALENCIA-TELLO, Diana Carolina; HACHEM, Daniel. La buena administración pública en el siglo XXI: análisis del caso colombiano. Veredas do Direito, Belo Horizonte, v.15, n.33, p.101-130, set./dez. 2018. Disponível em: <http://revista.domhelder.edu.br/index.php/veredas/article/ view/1326>. Acesso em: 10 dez. 2018.

VALLE, Vanice Regina Lírio do. Direito fundamental à boa administração e governança: democratizando a função administrativa. 2010. 254 f. Tese (Doutorado) - Curso de Pós-doutorado em Administração, Escola Brasileira de Administração Pública e de Empresas, Fundação Getúlio Vargas, Rio de Janeiro, 2010. Disponível em: <http://bibliotecadigital.fgv.br/dspace/bitstream/ handle/10438/6977/VANICE\%20VALLE.pdf?sequence=1\&isAllowed=y $\geq$. Acesso em: 10 dez. 2018.

VALLE, Vanice Regina Lírio do. Políticas públicas, direitos fundamentais e controle judicial. 2. Ed. Belo Horizonte: Editora Fórum, 2016.

VALLE, Vanice Regina Lírio do. Sustentabilidade das escolhas públicas: dignidade da pessoa traduzida pelo planejamento público. A\&C - Revista de Direito Administrativo \& Constitucional, Belo Horizonte, ano 11, n. 45, p. 127-149, jul/set, 2011. Disponível em: <http://www.revistaaec. com/index.php/revistaaec/article/view/212 2 . Acesso em: 02 set. 2018. 